\title{
Pharmacognostical Study of Monocot Medicinal Herb Kyllinga Triceps Rottb
}

Amit Upadhyay

S.O.S., Pharmaceutical Sciences Jiwaji University, Gwalior (M.P.)

\author{
Dr. Suman Jain \\ S.O.S., Pharmaceutical Sciences Jiwaji University, \\ Gwalior (M.P.)
}

\begin{abstract}
Kyllinga triceps in a small tufted herb upto 12in. high with a short rhizome and linear leaves, one half or nearly as long as the stem, found in forest of GwaliorChambal region. The plant is considered as diuretic, hepato protective, anti diabetic in Ayurvedic literatures plant is known as musta. It Cures kapha and pitta disorders in the present work detailed information related to pharmacognosy of kyllinga triceps rottb. (Cyperaceae) have been carried out, which would help investigators in identification of the plant
\end{abstract}

Keywords: Pharmacognosy, kyllinga triceps, musta, Ayurveda cyperaceous

\section{INTRODUCTION}

Many species of family Cyperaceae are used as a source of Ayurvedic Drug musta, kyllinga triceps rottb is one of the important source of musta. Plant is useful home remedy for indigestion, sprue diarrhea, intestinal problems, liver problems, congh, bronchitis, fever and poisonous affections. The drug in also used in epilepsy, loss of memory. Blood diseases and general debility the paste is applied in skin diseases and eye diseases. Mustaaristam, Ceriya Rashnadi Kasyam, Carngeryadi, Ghrtam Vyaghryadi leham etc. Are some of the preparations using the drug kyllinga triceps rottb.

No sufficient pharmacognostical work has been reported on this plant hence the present pharmacognostical investigation helps the researches for scientific identification of genuine sample to cure various human ailments.

\section{Materials and Method:-}

Plant Material-fresh rhizomes of kyllinga Triceps Rottb. Were collected from Bhoora Khon area of Shivpuri District of Gwalior region, authenticated by Dr. (Smt) M.D. Gupta (Asst. Director) and Mr. N.K. Pandey (R.O.) National Research institute of Ayurveda and Siddha (CCRAS), Ministry for health and family welfare, Govt. of India, Amkho, Gwalior (M.P.)

Ut most case was taken to select healthy plant and for normal organs the required sample of different organs were cut and removed from the plant and fixed in FAA (formalin-5ml $+70 \%$ ethyl alcohol-90ml). After $24 \mathrm{hrs}$ of fixing the specimens were dehydrated with graded series of tertiary butyl alcohol. Infilteration of the Specimens was carried out by gradual addition of paraffin wax. The specimens were cast into paraffin blocks.

\section{Sectioning:-}

The paraffin embedded specimens were section with help of rotary microtome the thickness of the sections was 10-12 $\mu \mathrm{m}$-after de waxing of the sections, they was stained with toluidine blue, the dye rendered pink colour to the cellulose walls, blue to the lignified cells, dark green to suberin, violet to the mucilage blue to the protein bodies etc. Where ever necessary 
sections were also stained with safranin and fast green.

For the study of stomata morphology venation pattern and trichome distribution paradermal sections were prepared.

Glycenine mounted temporary preparations were made for cleaved materials powdered materials of different parts were cleansed with $\mathrm{NAOH}$ and mounted in glycerin medium different cell component were studied and measured.

\section{Photomicrographs-}

Microscopic descriptions of tissues are supplemented with micrographs. Photographs of different magnifications were taken with Nikon labphot 2 microscopic unit for normal observations bright field was used for the study of crystals, starch grains and lignified cells, polarized light was employed magnification of figures we indicated by the scale bars.

\section{Results:-}

\section{Microscopy of leaf}

The leaf is folded adaxially in the form "V", the two margins beings expanded laterally. The surface of the leaf is smooth and glabrous. The abaxial side is evern while the adaxial side is somewhat uneven due to the presences of dilated bulliform cells,. The midrib is semicircular on the bulliform cells. The midrib present is $250 \mathrm{um}$ in vertical plane and $220 \mathrm{um}$ in horizontal plane there is a single prominent circular vascular bundle in the midrib. The bundle has two wide circular metaxylem elements and a crushed circular protoxylem lacuna. Phloem occurs in a circular patch in between the metaxylem element. The bundle is surrounded by a single layer of sheath of parenchyma cells. On either side of the midrib bundle, there is a thick mass of fibers close to the epidermal layer.

Lamina is 150 um thick it has wide dilated epidermal layer on the adaxial side, the cells are radially oblong and thin walled. At certain places, the adaxial epidermal become highly dilated and vertically elongated forming bulliform cells or motor cells. These cells will shrink during dry weather and make the lamina to fold adaxially. During moist weather, these cells dilate and make the lamina to unfold.
The abaxial epidermis is thin made up of circular or barrel shaped cells. In the adaxial epidermis there are eight or more mall nests of fibers located on the surface of the epidermis. The lamina has several lateral vascular bundles located in horizontal row with in the mesophyll tissue. The lateral vascular bundles are similar to the midrib bundles and have two meraxylem elements protoxylem lacuna, phloem mass and bundle sheath parenchyma. Due to presence of bundle sheath ill in conformed as en plant.

The mesophyll tissue is not differentiated into palisade and spongy parenchyma. It consists of compact spherical parenchyma cells with dense chloroplast, paracytic type of stomata are present with stomatal - number14.

\section{Microscopy of culm (stem)}

The aerial stem or the culm is triangular in cross sectional view with three prominent wings. The wings are semicircular.

The epidermis of the culm has fairly thick epidermal layer made up of rectangular or squrish cells. With thick cuticle. The pith is wide, homogeneous and paranchymatous. The cells are thin walled and compact. Thick masses of fibers (sclerenchyma) are seen on either side of the wings

The vascular system of the culm consists of outer vascular bundles and inner vascular strands.

The Outer vascular strands are smaller circular and collateral, they have two metaxylem elements, protoxylem lacuna and small cluster of phloem. Each bundles is surrounded by parenchymatous bundle sheath and chlorenchyma cells.

The inner vascular bundles occur with inner zone of the stem, next to the outer vascular bundles. The inner bundles are less in numbers, but large in size, elliptical in shape. They also have typical monocot type of metaxylem-protoxylem element, phloem in between the metaxylem element.

\section{Microscopy of Root}

The root in thin and fibrous it has crushed epidermal layer. The cortex has outer zone of three or four layers of shrinken parenchyma cells and inner zone of much wider air-chambers. The endodermis and pericycle are thick walled and sclerenchyma cells are present. 
The vascular cylinder has a wide circular central metaxylem and several radial rows of protoxylem elements. Phloem occurs in between the metaxylem elements.

\section{Microscopy of Rhizome:}

The rhizome is the underground stem which is short, creeping, sheathed by brownish leaf sheath. The leaf sheath has two layers of epidermis with large airchambers in between. The outer and inner epidermal layers are single layered with rectangular cells, the margins of the leaf sheath is two or three layered and there are large, circular vascular bundles placed in the air-chambers in a single row. There are smaller vascular bundles situated a along the outer epidermis. In the region where the vascular bundles occurs, the epidermis becomes three layered.

The rhizome is circular and even in outline. It is $2 \mathrm{~mm}$ in diameter. It has single layered epidermis. The epidermal cells are rectangular, narrow and thin walled. There is wide cortex comprising of homogenous parenchyma tissue. The cortical cells are small, angular thin walled and compact. The cortex is 700 um wide.

The steel is central, circular and 240um in diameter. It has a thick endodermis which consists of radially oblong cells with thick inner and radial walls. The pericycle is single layered with spindle shaped parenchymatous cells.

Inner to the endodermis is a thick sheath of thick walled sclernchyma cells. Within the sclerenchyma sheath are seen small nest of phloem and one or two solirary xylem elements the sclerenchyma cells are lignified. In the central part of stele are several diffusely distributed vascular bundles. The outer bundles are smaller and central ones are large. The vascular bundles are amphivasal type, they have central core of phloem and surrounded by one or two layer of xylem. The xylem elements are angular, thick walled and lignified. The pith cells are parenchymatous, thin walled and compact. Some of the pith cells have dense mass of tannin.

\section{Microscopy of inflorescence}

The inflorescence is a condensed spike conical in shape and terminal in position, it is white, the peduncle is reduced. In sectional view, the inflorescence axis has many ridges and furrows. The florets are altached to the axis in the furrows with a short stalk. The floret have thin, membranous perianth members. The inflorescence axis has central pith and peripheral zone of one or two rows of vascular strands. Each floret has a single ovary single ovule. The ovary is broad at the apex and conical at the base. The ovary develops into small nutlet with single seed.

The another are two lobed and four chambered. The anther wall is thin with spiny outer surface. The pollen grains are minute, triangular with smooth exine.

\section{Powder Microscopy}

Powder of the rhizome, aerial stem and leaf was studies under the microscope and the following elements were observed.

\section{Vessel elements}

The vessel elements are long, narrow and cylindrical. They are 90um and $20 \mathrm{um}$ wide. They have simple, circular, horizontal perforation plate. They lateral wall pts are elliptical and dense.

\section{Xylem fibers}

They have long narrow pointed ends. The walls are thick and lignified pits are absent they are 400-550 um long.

3. Vessel element and fiber of the aerial stem are much longer and narrower. The vessel elements $550 \mathrm{um}$ long the fibers are also thin and long upto $600 \mathrm{um}$.

4. The epidermal cells are vertically oblong and parallel to each other. The anticlinal walls are thick and straight. They are densely pitted. The cell are 50-110 um long 20 um wide. The stomata are anomocytic and occur in vertical rows.

5. Parenchyma cell of different shape and size are seen in the powder.

Presence of long narrow xylem fibers with pointed ends, presence of densely pitted anticlinal walls and presence of anomocytic stomata in vertical rows are the characteristic features of powder microscopy. 


\section{FIGURES:-}

Fig- 1: Ts of leaf showing folded adaxially in the form of "V", the two margins being expanded laterally

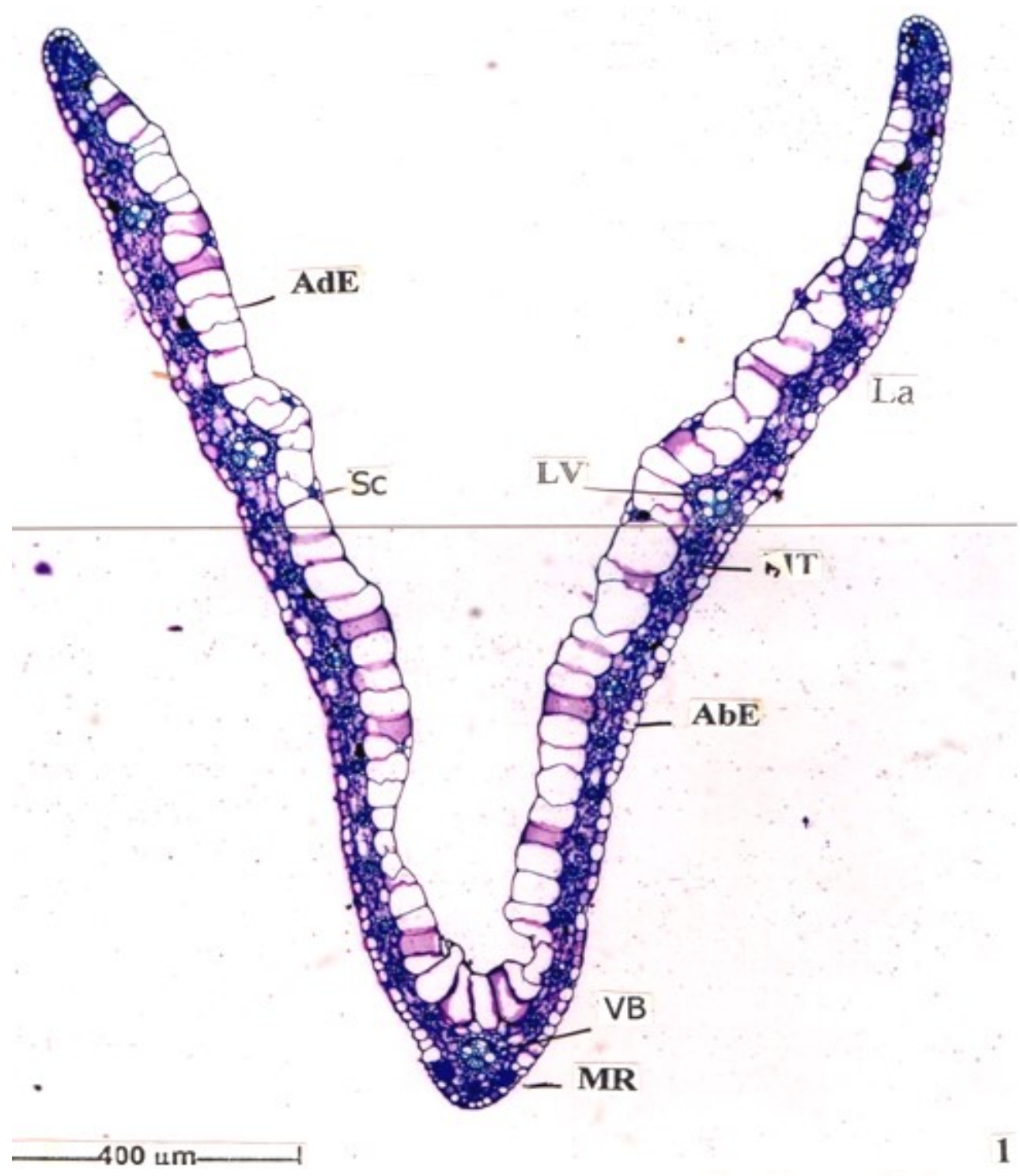

AbE- Abaxial epidermis: AdE-Adaxial epidermis: La-Lamina:

Lv- Lateral vein : MR- Midrib: Mt- Mesophyll tissue:

Sc-Sclerenchyma: VB - vascular Bundle. 
Fig-2: Anatomy of the leaf:-

1. T.S. of the leaf through midrib with lamina

2. Midrib and lamina enlarged.

3. T.S. of the leaf margin.

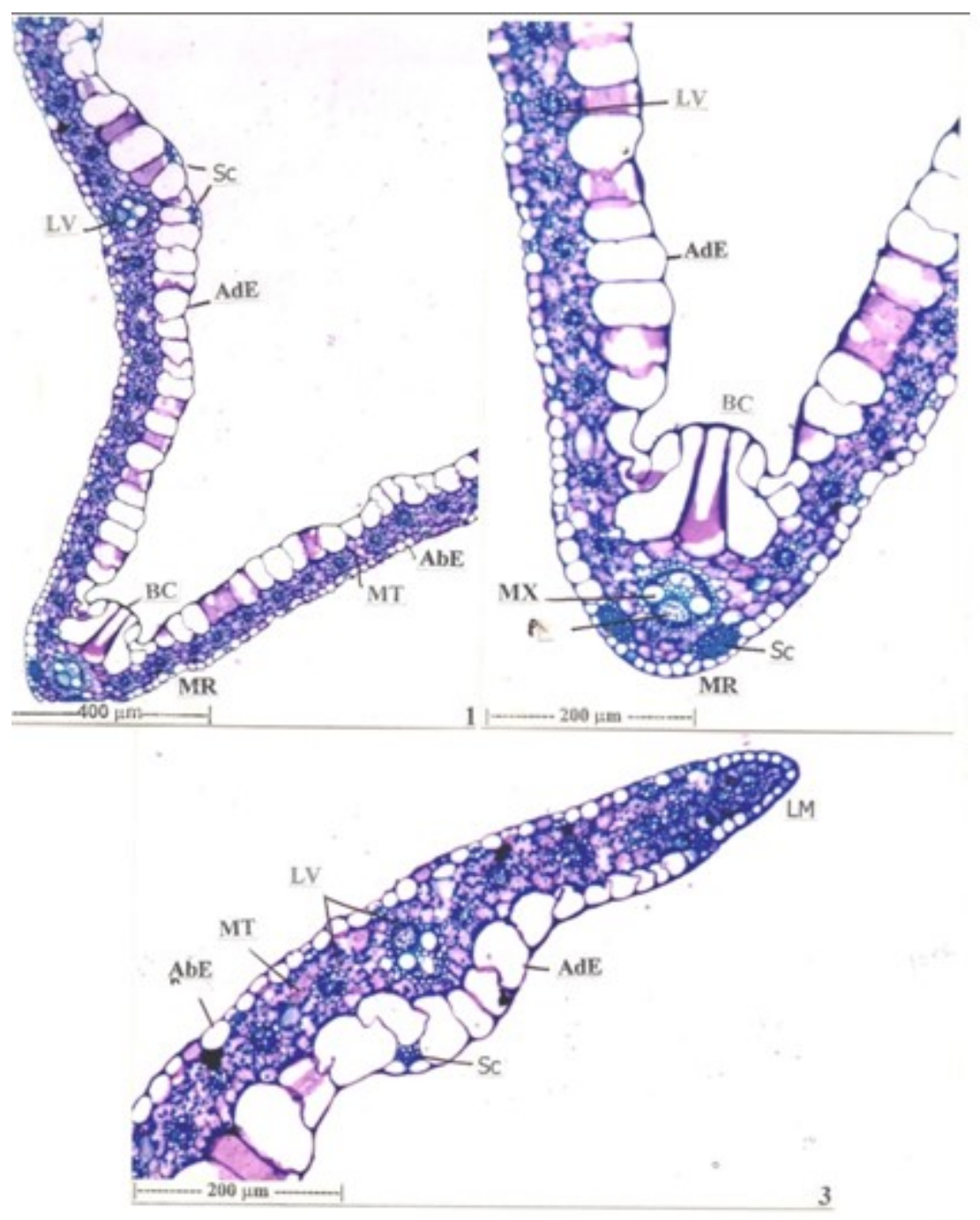

AbE=- Abaxial epidermis: AdE- Adaxial epidermis: Bc- Bulliform cells

LM-leaf margin: LV-lateral Vein: MR-Midrib: MT- Mesophyll tissue: MX-meta xylem: Ph-Phloem: ScSclerenchyma. 
Fig-3: Anatomy of the stem (culm) and Root:

1. T.S. of culm entire view

2. T.S. of root ground plane
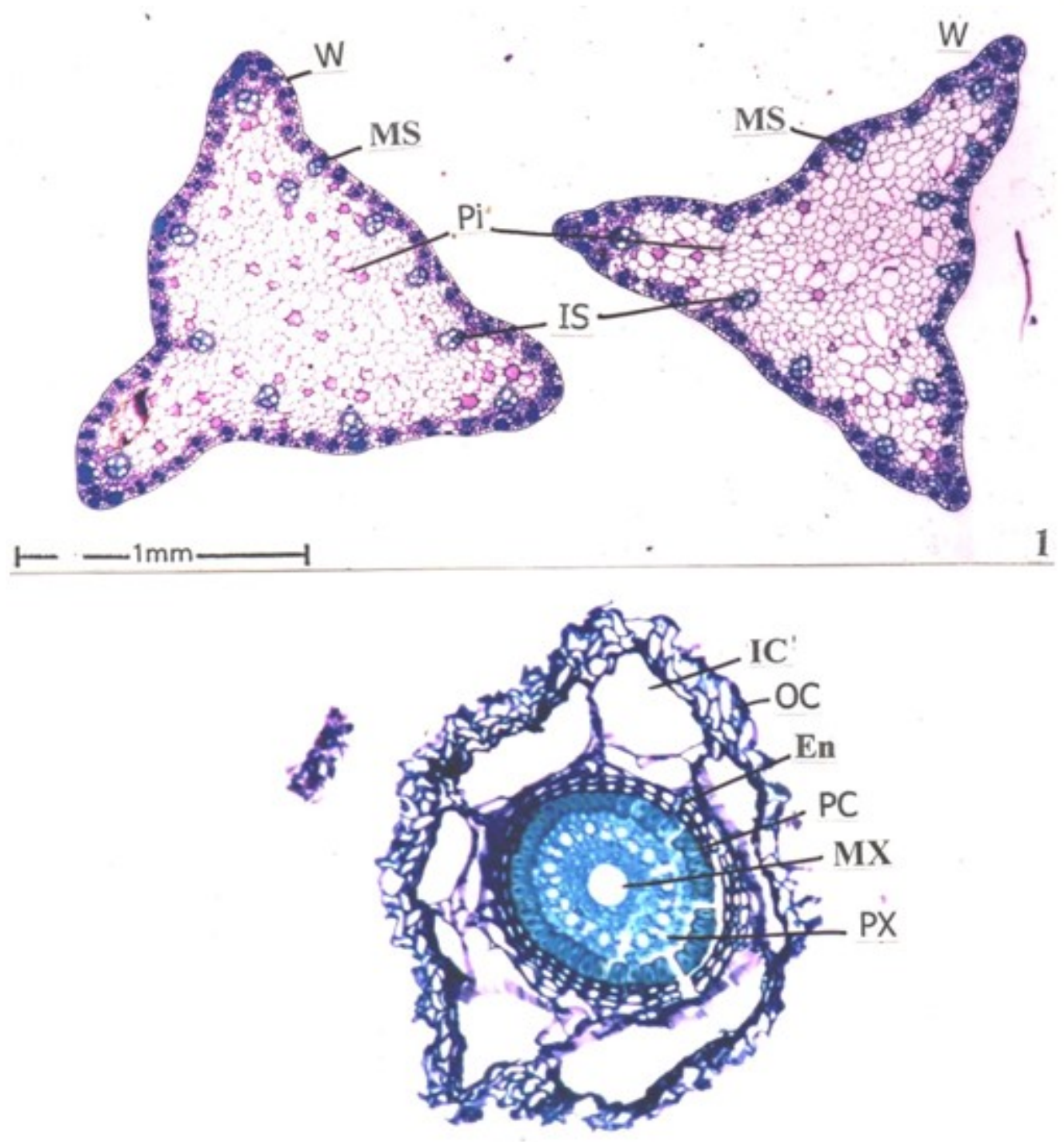

En- Endodermis: IC-Inner Cortex: Is- inner vascular strand: MS- Marginal Strand: MX-metaxylem: OC-Outer cortex: Pi-pith: Pc-Pericycle: PX- Protoxylem: W-Wing. 
International Journal of Trend in Scientific Research and Development (IJTSRD) ISSN: 2456-6470

Fig-4: Structure of the (culm) Stem

1. T.S. stem half portion enlarged.

2. T.S. stem a wing portion enlarged.

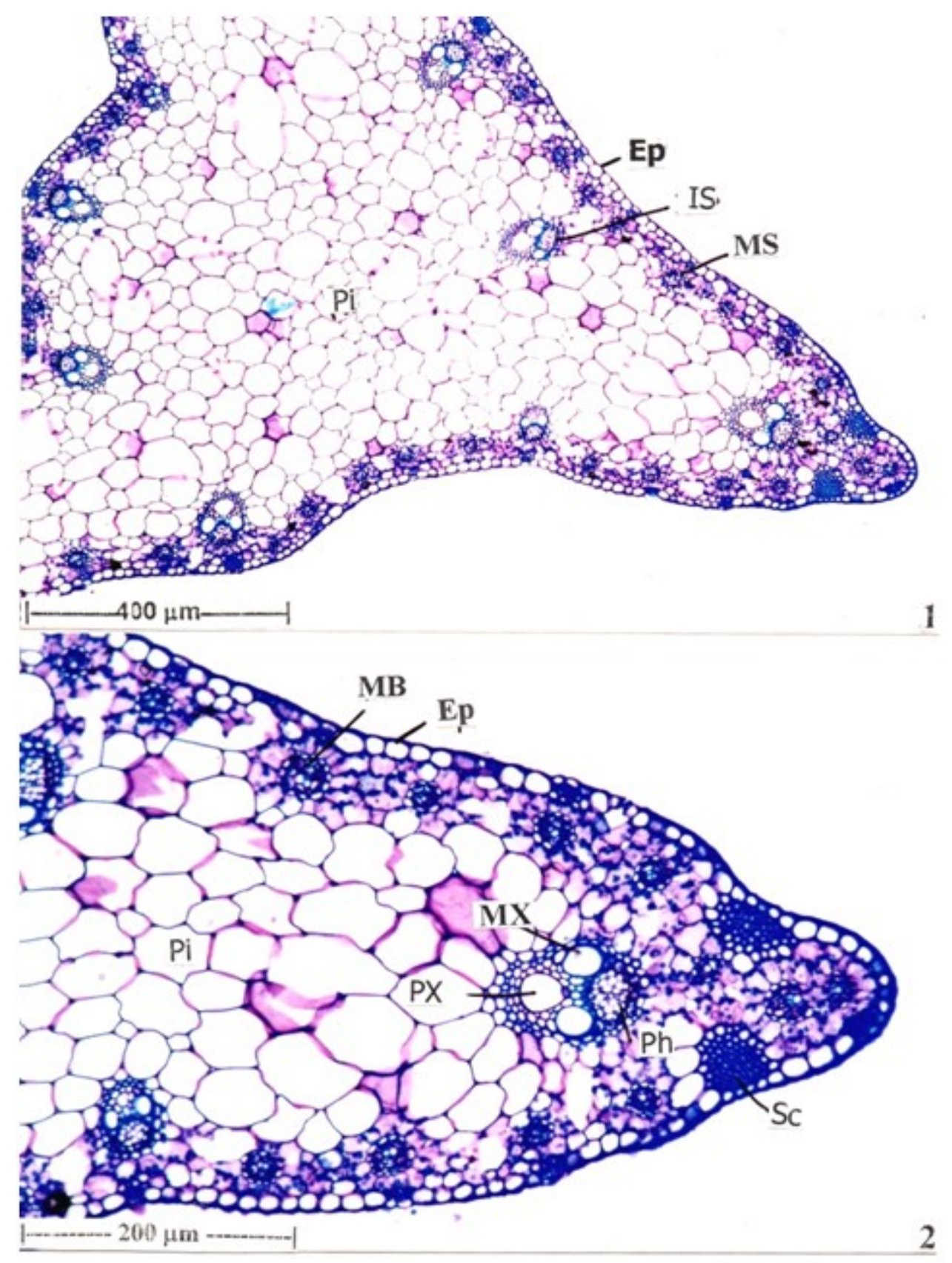

E- Epidermis: Is - Inner vascular strand: MB-marginal Bundle: Mx- Metaxylem: Ph-phloem: Pi- Pith Protoxylem: Sc- sclerenchyma. 
International Journal of Trend in Scientific Research and Development (IJTSRD) ISSN: 2456-6470

Fig-5: Anatomy of the Rhizome:

1. T.S. of Rhizome entire view.

2. T.S. Rhizome a sector enlarged.

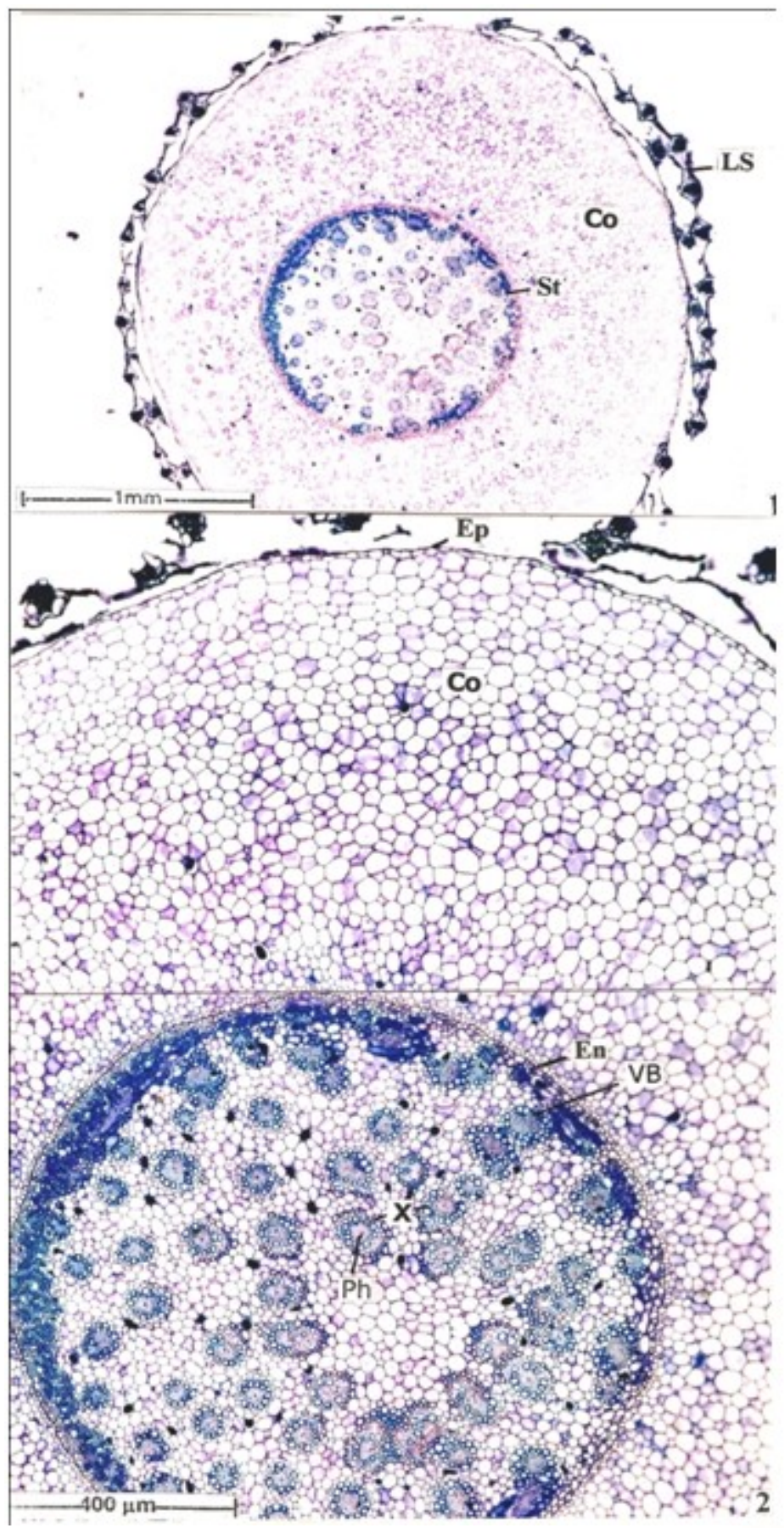

Co- Cortex: Ep-epidermis: En-Endodermis: LS- leaf Sheath: Ph- Phloem: St-stele: VB-vascular bundle: X- xylem. 
International Journal of Trend in Scientific Research and Development (IJTSRD) ISSN: 2456-6470

Fig-6: Structure of the Rhizome vascular bundles:

1. Leaf sheath and outer vascular bundles.

2. Inner and central vascular bundle enlarged.

3. "Amphivasal"-type of vascular bundles enlarged.

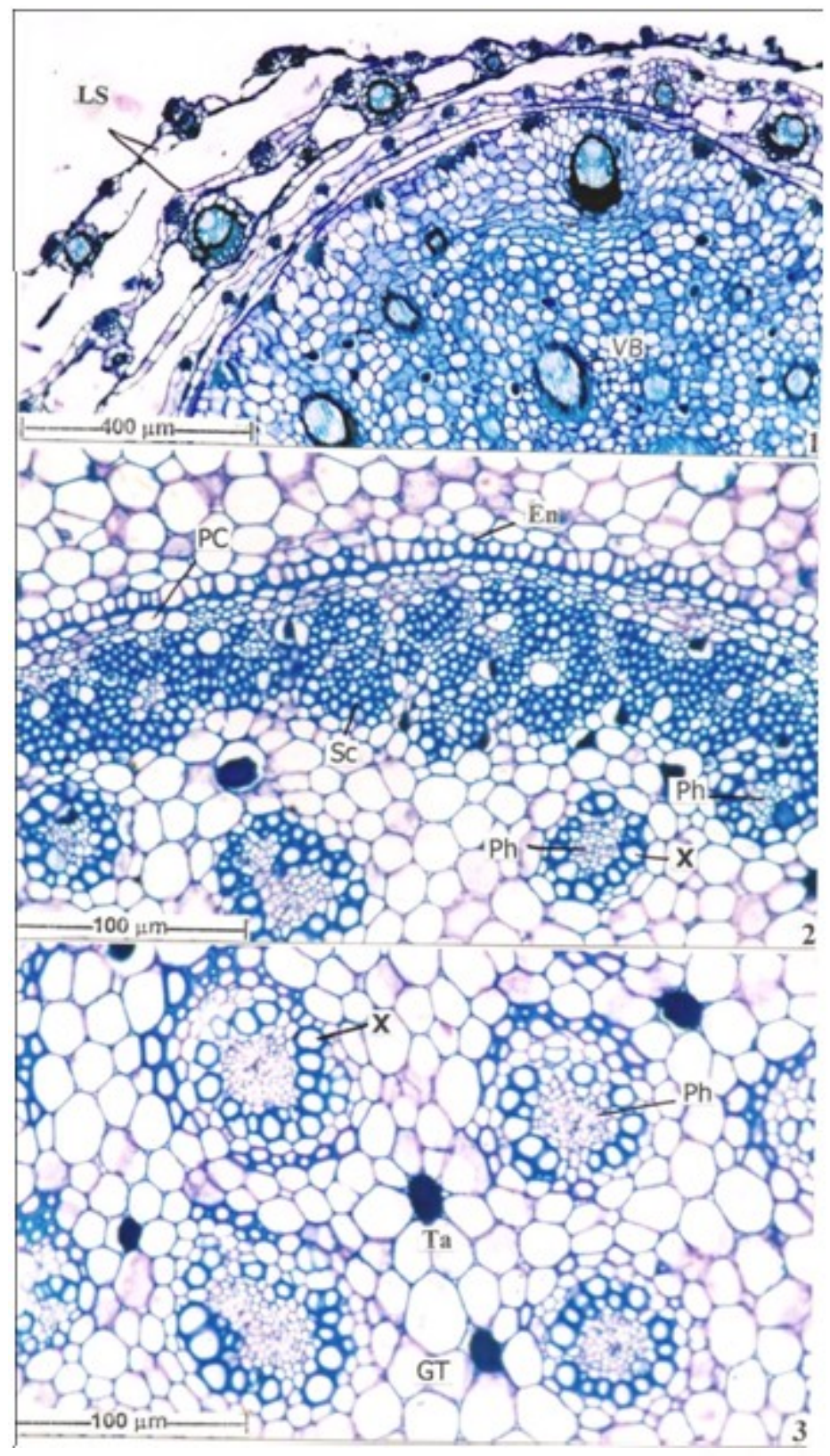

n-Endodermis: GT ground tissue: LS- Leaf sheath: Pc- pericycle:

Ph- Phloem: Sc- sclernchyma: Ta- Tanniniferous idioblast:

VB- vascular bundle: $\mathrm{X}$ - xylem. 
International Journal of Trend in Scientific Research and Development (IJTSRD) ISSN: 2456-6470

Fig-7: Structure of the Cortex, inner vascular bundle and central vascular bundle

1. Under bright field microscope

2. Under Polarized light microscope

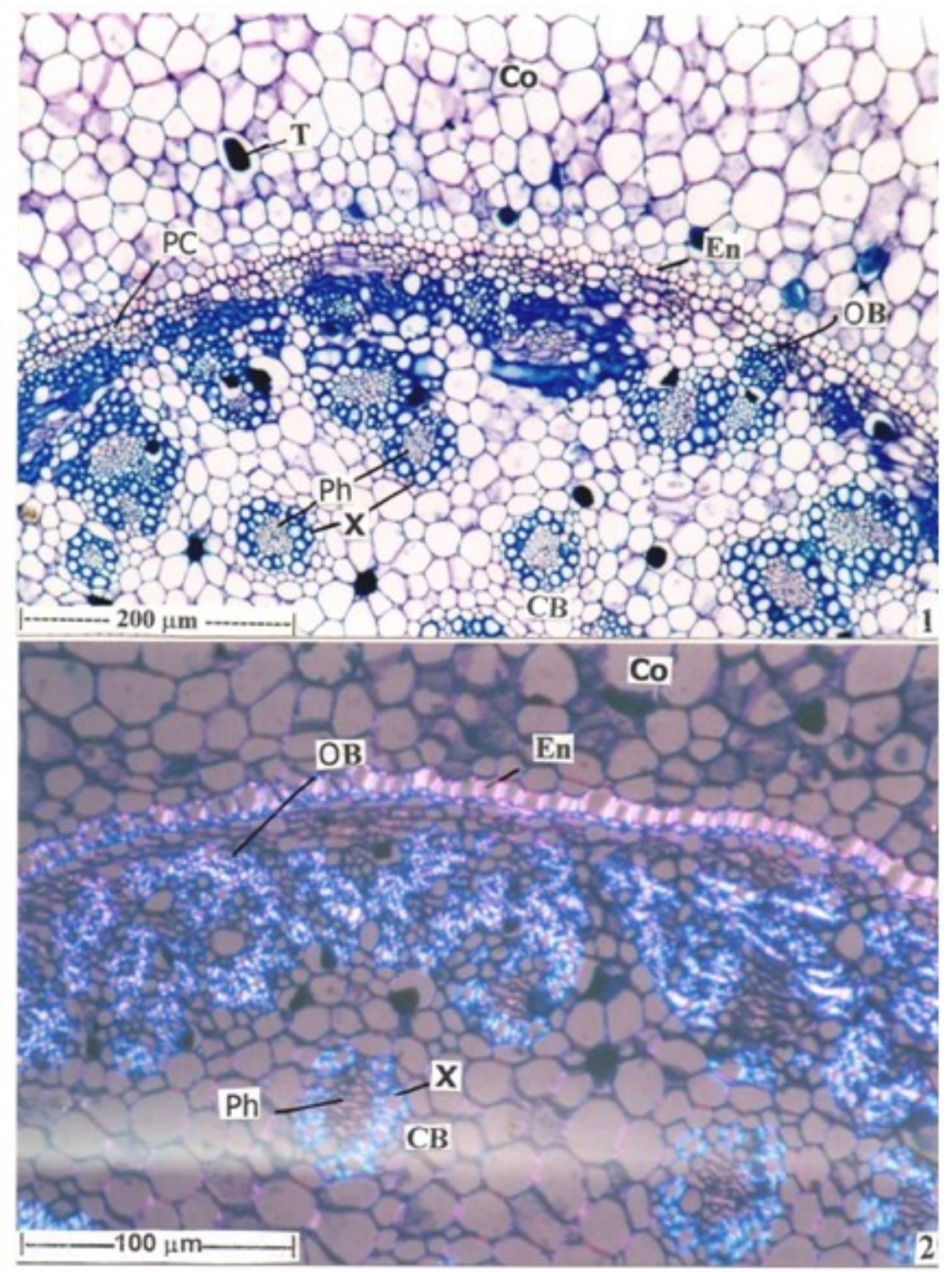

CB- Central Vascular Bundle: Co-Cortex: En-Endodermis:

OB-Outer Vascular Bundle Pc- Pericycle, Ph-Phloem

T-Tanniniferous idioblasy: $\mathrm{X}$-xylem 
International Journal of Trend in Scientific Research and Development (IJTSRD) ISSN: 2456-6470

Fig-8: Anatomy of the Inflorescence

1. T.S. Inflorescence half portion-enlarged

2. Inflorescence axis and vascular strand enlarged.

3. Structure of the perianth, Pollen, Anther and Ovary.

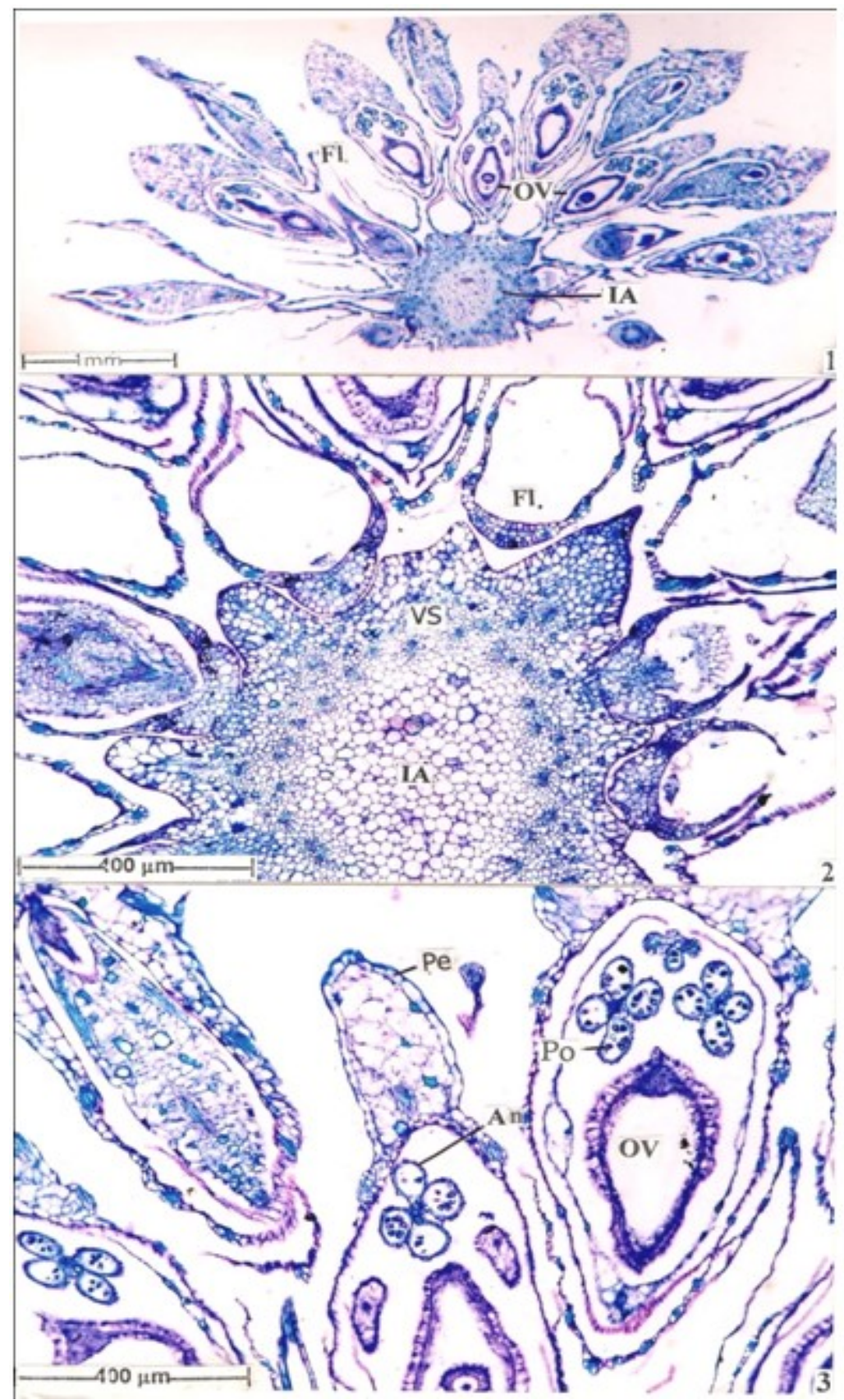

An- Anther" Fi-Florets: IA-inflorescence axis: Ov-Ovary: Pe-perianth

Po-Pollen: VS- Vascular Strand. 
Fig-9: Powder Microscopy of the Rhizome

\section{1,2 Vessel Elements}

3, 4 Vessel Element and fibers.

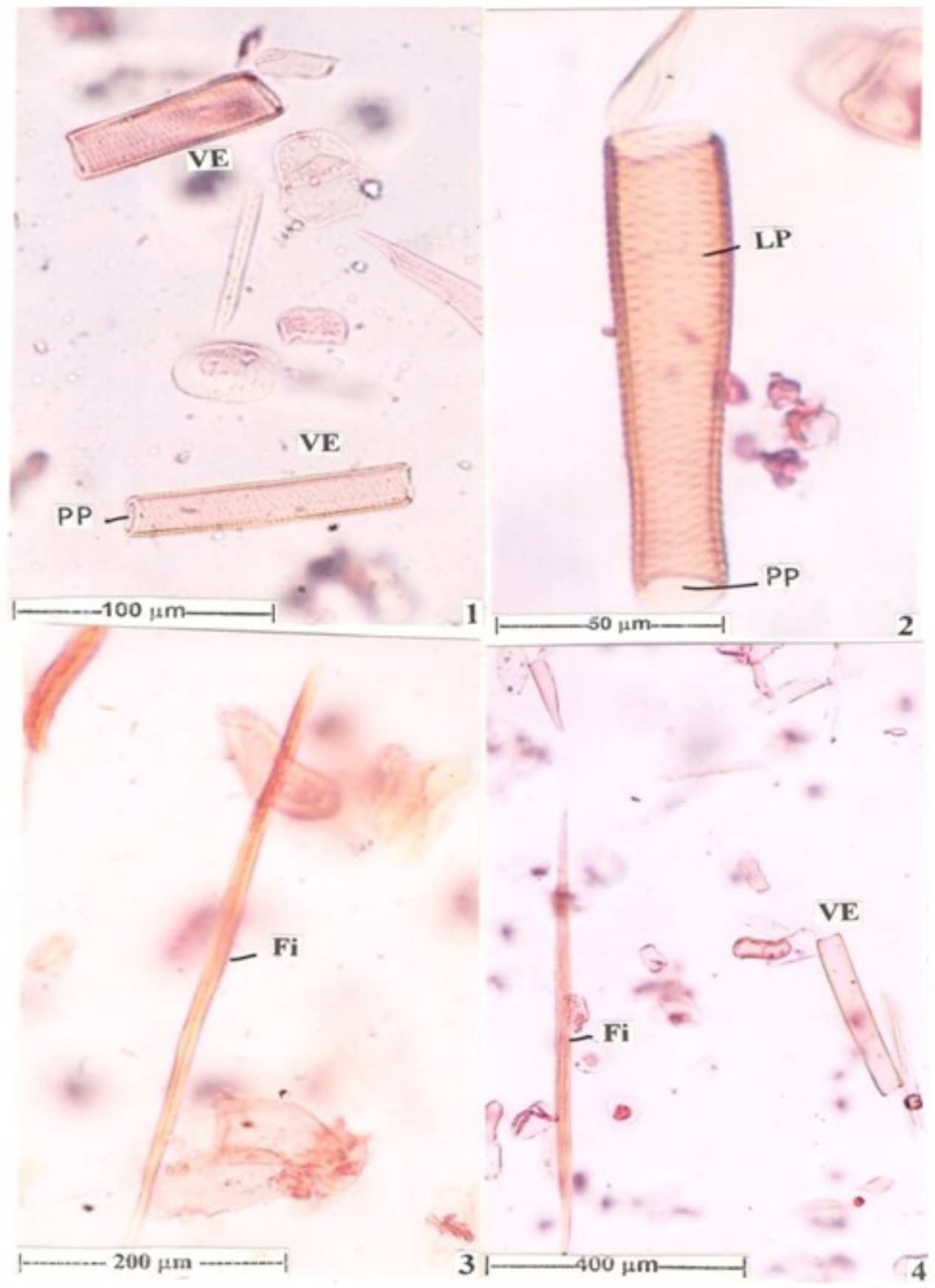

Fi- Fibers: LP-Lateral Pits PP- Perforation plate: VE- Vessel Element 
Fig-10: Powder Microscopy of the leaf and Culm:

1. Abaxial epidermis and stomata

2. Fibre, Paranchyma cell and vessel element of (stem) culm.
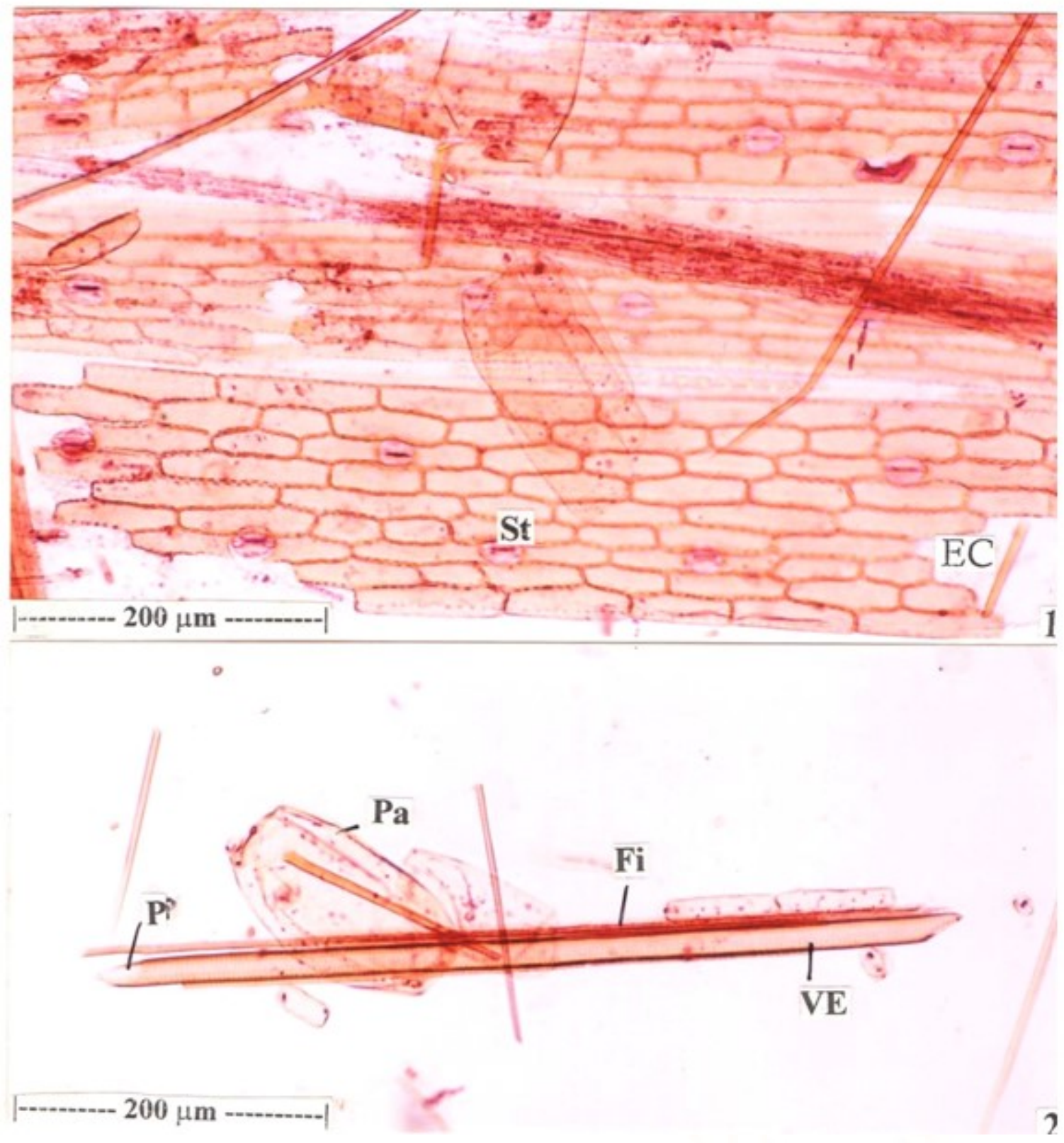

EC- Epidermal cell: Fi-Fiber: Pa-Parenchyma cells. PP-Perforation plate: St- stomata: VEVessel Element

\section{CONCLUSION}

The present Pharmacognostical study would help in the identification of kyllinga triceps rottb. Morphological characters such as habit, size, height, colour, odour etc. are key characters to differentiate plant kyllinga triceps from other similar plants.
Anatomical characters such as presence of dilated bulliform cells, semicircular midrib, presence of spherical parenchyma cells and paracytic stomata would be helpful in identification of leaves. 
Rhizome can be examined by the presence of thick endodermis, which cantains radially oblong cells, pericycle is unes al ized with single layered, spindle shaped parenchymatous cells. Pith cells contains dense mass of tannin.

Inflorescence consist of 1-3 spikes, each floret has a single ovary with single ovule. Powder microscopy suggests that vessel elements are $90 \mu \mathrm{m}$ long and 20 $\mu \mathrm{m}$ wide while xylem fibers 400-550 $\mu \mathrm{m}$ long. Pharmacognostical study of plant kyllinga triceps would help in the Quality preparation of several Ayurvedic drug formulations. Further studies are necessary to carryout research in pharmacological and phytochemical standardization for authentication of crude drugs.

\section{ACKNOWLEDGEMENT}

Authors are thankful to All the faculty members of botany and pharmacy department of, Jiwaji University, Gwalior (M.P.) and we are also thankful to Mr. N.K. Pandey, (R.O.), C.C.R.A.S. Amkho Gwalior, for their kind support and encouragement.

\section{REFERENCE}

1) Narayanswami R.V., K.N. Rao, A. Rahman, Outlines of botany 9th Edition 1992, S. Vishwanathan Printers and Publishers Chennai, 309-310.

2) Orient longman, Indian Medicinal Plants, Ist edition, 1994, orient longman, Ltd, madras, 285 286.
3) Johan Sen DA, Plant microtechnique, MC Graw Hill New York, 1980,183-203.

4) Nadkarni KM, Indian Materia Medica, popular prakashan pvt. Ltd., vol. I, 1976.

5) Sass J.E., Elements of Botanical Microtechnique 1940, MC graw Hill Book co. New York, 222.

6) Gamble, J.S., flora of the Presidency of madras 1935, I II III, Botanical Survey of India, Calcutta India.

7) Henry A.N., Kumari G.R. Chitra V., flora of tamil Nadu, 1987, Vol. I II III, Botanical survey of India Southern Circle, Coimbatore.

8) O. Brien T.P., feder N. and MC cull M.E. , Polychromatic staining of plant cell walls by toluidine blue, protoplasma, 1964, 59, 364-373.

9) Sharma Shikha, Mistry Sunil, Lariya Shailendra, Int. R.J. Pharm SC., 2013, 04 (01), 14-20.

10) Kirtikar K.R., Basu B.D. Indian Medicinal Plants, 2nd edition, part-4, 1991, 331-332.

11) Mukherjee S.K., College botany, Ist edition, vol. -3 New Central book agency pvt. Ltd. Kolkata, $1984,75$.

12) Shukla Priti, Mishra P. Shital, An introduction to taxonomy of angiosperms Ist edition, vol.-4, 2002, Vikas publishers, New Delhi, 515-518. 